\title{
Modifikasi Claroline dengan Metode Pembelajaran Computer-Supported Collaborative Learning (CSCL) Berbasis Konstruktivisme
}

\author{
Made Santo Gitakarma ${ }^{1)}$, Luh Putu Ary Sri Tjahyanti ${ }^{2)}$ \\ 1) Program Studi D3 Teknik Elektronika, Universitas Pendidikan Ganesha, Jl. Udayana, \\ Singaraja, Bali 81116, Email : santo@undiksha.ac.id \\ 2) Program Studi Teknik Informatika, AMIKOM, JI. AMIKOM-ASM Kekalik Mataram, NTB 83125 \\ E-mail: tjahyanti@cs.its.ac.id
}

\begin{abstract}
ABSTRAK
Claroline merupakan salah satu sistem eLearning untuk manajemen pelatihan (Course Management System). Pembelajaran kolaboratif dengan sistem eLearning dapat dilakukan dengan memanfaatkan Claroline. Metode pembelajaran kolaboratif berbantuan komputer atau web sering disebut sebagai Computer-Supported Collaborative Learning (CSCL). Metode ini bertujuan sebagai wadah untuk mendukung suatu kelompok pelajar dalam belajar bersama secara efektif dengan cara berbagi informasi dan mendiskusikan masalah yang diberikan. Konsep konstruktivisme dapat diterapkan dalam sistem ini dengan memberikan perlakuan (treatment) topik yang sesuai kemudian dilakukan Pretest dan Posttest. Pretest untuk mengukur pengetahuan awal (prior knowledge) pelajar yang diklasifikasikan ke dalam level belajar (level 1 hingga 4) dan Posttest untuk mengukur tingkat pencapaian hasil belajar. Pengujian dilakukan di Jurusan Teknik Informatika AMIKOM Mataram untuk topik Software Requirements pada perkuliahan Rekayasa Perangkat Lunak. Hasil pengujian pada 30 mahasiswa didapatkan nilai rata-rata Pretest sebesar 4,68 dan nilai rata-rata Posttest sebesar 8,12. Hasil evaluasi sistem dengan Kuesioner Pemakaian (Usability Questionnaire) menyatakan sebagian besar pengguna SCK setuju adanya sistem ini dengan rata-rata setuju sebesar $84,42 \%$. Dan hasil uji reliabilitas instrumen Kuesioner Pemakaian didapatkan koefisien reliabilitas (Cronbach) sebesar 0,57.
\end{abstract}

Kata kunci: pembelajaran kolaboratif, konstruktivisme, CSCL, eLearning, usability questionnaire, cronbach.

\section{Pendahuluan}

Lingkungan pendidikan saat ini sedikit demi sedikit beralih dari cara tradisional yaitu lingkungan belajar di kelas menjadi pembelajaran kolaborasi dan atau mandiri secara adaptif melalui perkembangan Internet, teknologi mobile dan wireless [1]. Teknologi informasi menawarkan teknik komunikasi berbasis web dan pendekatan kolaborasi tradisional diadopsi menggunakan basis web [2].

Collaborative Learning $(\mathrm{CL})$ adalah sebuah strategi instruksional yang terstruktur dan sistematis dimana sekelompok pelajar bekerja sama memaksimalkan pembelajaran rekanrekan mereka [3]. Bentuknya dapat berupa dialog, negosiasi dan argumen untuk memecahkan masalah yang mereka miliki.

Computer supported collaborative learning (CSCL) adalah pembelajaran kolaboratif dimana sekelompok pelajar berada dalam sebuah jaringan komputer dalam rangka memaksimalkan individu, tim, dan hasil pembelajaran untuk mencapai tujuan melalui diskusi dan asistensi yang bermanfaat [4]. Saat ini ada beberapa penelitian sistem pembelajaran kolaborasi berbantuan komputer seperti sistem CSCL berbasis manajemen pengetahuan (CLSKM) [5], CSCL berbasis kontrak pembelajaran [4], dan CSCL konsensus berbasis struktur pohon biner [6]. Konsep-konsep penelitian tersebut masih berfokus pada tujuan akhir pembelajaran, dan masih kurang dalam penilaian (assessment) selama proses pembelajaran berlangsung.

Makna pengetahuan yang didapat dalam pembelajaran itu tidak semata-mata didapat langsung dari guru maupun informasi yang ada di dalam sistem. Namun, makna yang dibangun sangat bergantung pada struktur kognitif yang telah ada sebelumnya (prior knowledge) pada 


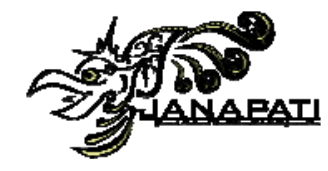

ISSN 2089-8673

Jurnal Nasional Pendidikan Teknik Informatika (JANAPATI)

Volume 1, Nomor 1, Maret 2012

masing-masing individu pelajar, dan sifatnya personal. Oleh karena itu, teori belajar yang sesuai untuk hal ini adalah model pembelajaran konstruktivisme.

Dalam penelitian ini akan dilakukan pembuatan sistem CSCL berbasis konstruktivisme. Pertama-tama setiap anggota perkuliahan mendaftar sebagai user ke dalam sistem. Mereka diklasifikasikan sebagai Dosen dan Mahasiswa. Mahasiswa diberikan Pretest, Quiz, Posttest dan melakukan aktivitas pembelajaran kolaboratif.

\section{Landasan Teori}

\subsection{Model Pembelajaran Konstruktivisme}

Saat ini pengetahuan lebih dipandang sebagai suatu proses konstruksi yang terusmenerus, terus berkembang dan berubah dibandingkan dipandang hanya sebagai kumpulan fakta-fakta. Konstruktivisme adalah salah satu filsafat pengetahuan yang menekankan bahwa pengetahuan adalah konstruksi (bentukan) kita sendiri. Pengetahuan tidak dapat dipindahkan begitu saja dari kepala seseorang (guru) ke kepala orang lain (murid). Murid itu sendirilah yang memberi makna terhadap apa yang telah diajarkan guru, dengan menyesuaikannya dengan pengalaman-pengalaman mereka. Pengetahuan tidak bersifat deterministik, tetapi suatu proses menjadi tahu.

Model pembelajaran berbasis konstruktivisme lebih menekankan pada pembentukan makna tersendiri bagi pelajar, menghubungkan dengan pengetahuan awal (prior knowledge), dan mengkonstruksinya menjadi pengetahuan baru. Gagasan-gagasan dari pengetahuan sebelumnya direstrukturisasi melalui pengalaman sensori baru yang diterimanya. Disinilah pelajar memahami apa dan bagaimana belajar bermakna (meaningful learning).

Model belajar konstruktivis diawali dengan identifikasi kompetensi yang ingin dicapai, kemudian dilanjutkan dengan menetapkan isi (produk) belajar yang ingin dihasilkan. Model belajar konstruktivis didasari adanya prior knowledge (pengetahuan awal) yang dimiliki pelajar, sehingga pengetahuan awal ini perlu diidentifikasi dan diklarifikasi untuk menentukan perencanaan program pembelajaran yang ingin dilakukan dan bagaimana cara implementasinya.

Restrukturisasi ide-ide pelajar terdiri dari tiga bagian yaitu: klarifikasi dan pertukaran ide-ide pelajar, penyajian konflik kognitif, dan pengkonstruksian ide-ide baru. Tahap akhir model pembelajaran konstruktivisme ialah evaluasi. Evaluasi sangat berguna untuk melihat seberapa jauh peningkatan hasil belajar yang dicapai dan evaluasi terhadap tahapan-tahapan dalam model pembelajaran konstruktivisme. Lebih jelasnya dapat dilihat pada Gambar 1. 
ISSN 2089-8673

Jurnal Nasional Pendidikan Teknik Informatika (JANAPATI)

Volume 1, Nomor 1, Maret 2012

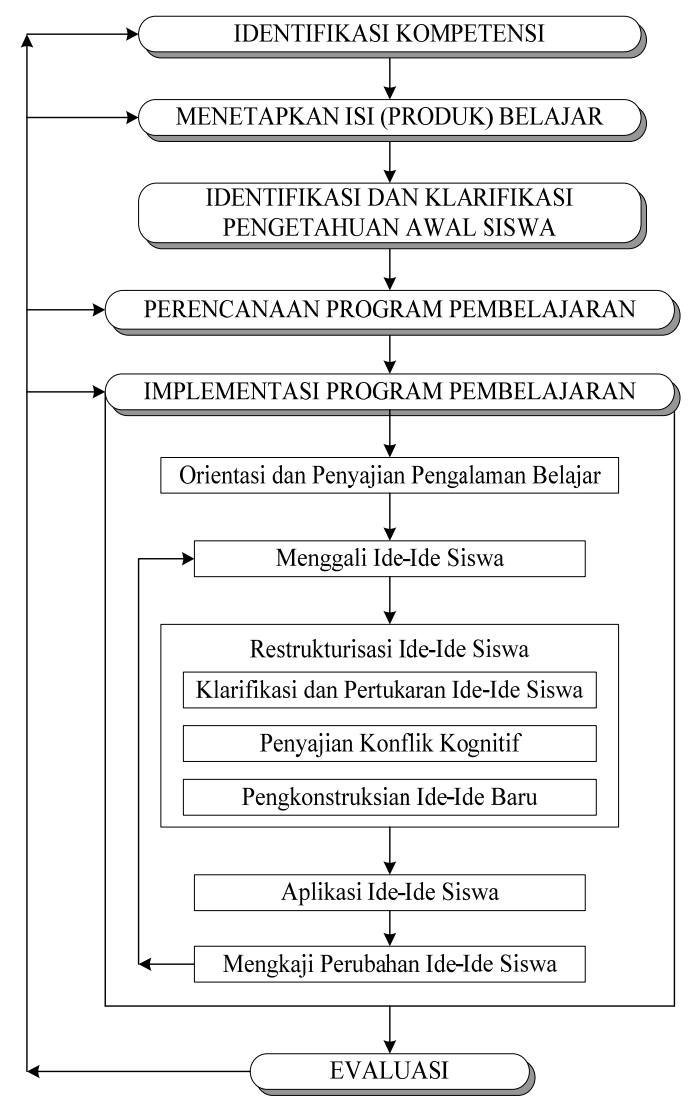

Gambar 1 Diagram alur model belajar konstruktivis

Pendekatan konstruktivisme dalam pembelajaran ialah pelajar berpartisipasi secara aktif dalam proses pembelajaran mereka sendiri dan membangun pengetahuan mereka sendiri ${ }^{[5]}$. Sebenarnya, pembelajaran kolaboratif juga terletak dalam paradigma konstruktivisme sosial. Fitur-fitur kritis pembelajaran konstruktivisme adalah sebagai berikut : [7]

1. Semua pengetahuan yang dibangun melalui proses abstraksi reflektif.

2. Struktur kognitif dalam pelajarnya memfasilitasi proses pembelajaran.

3. Struktur kognitif dalam individu-individu dalam proses pembangunan konstan.

Jika gagasan tentang pembelajaran konstruktivis diterima, maka metode-metode pembelajaran dan pengajaran harus disetujui.

\subsection{Pemodelan CSCL Berbasis Konstruktivisme}

Sistem CSCL yang akan dibuat dalam penelitian ini terdiri dari lima bagian yaitu: strategi pembelajaran kolaboratif, perpustakaan informasi pengguna, antarmuka mahasiswa, antarmuka dosen, dan administrasi. Struktur sistem CSCL ditunjukkan pada Gambar 2.

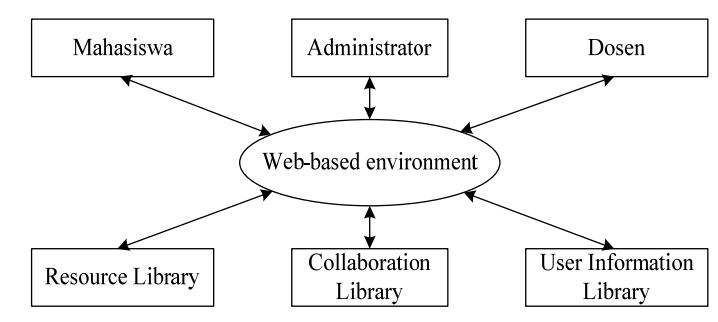


ISSN 2089-8673

Jurnal Nasional Pendidikan Teknik Informatika (JANAPATI)

Volume 1, Nomor 1, Maret 2012

Gambar 2 Struktur sistem CSCL

Konsep konstruktivisme akan diterapkan dalam sistem ini sehingga menjadi Sistem CSCL berbasis konstruktivisme (SCK). Open source Claroline dimodifikasi sehingga sesuai dengan konsep SCK. Modifikasi ini meliputi modifikasi umum dan modifikasi khusus. Modifikasi umum yaitu penyempurnaan bahasa untuk tujuan sistem dalam perguruan tinggi dan tampilan sistem. Modifikasi khusus meliputi :

- Penambahan menu Pretest di dalam menu setiap topik yang dibuat. Pretest ini dapat mengambil soal-soal dari Bank Soal yang disetting oleh Dosen bersangkutan, kemudian Pretest secara otomatis aktif saat pertama kali Mahasiswa masuk ke Topik dan tidak aktif jika mahasiswa sudah pernah masuk ke Topik. Nilai Pretest akan diklasifikasikan menjadi 4 level yang menentukan level Dokumen-dokumen yang dapat diakses.

- Menu Dokumen dimodifikasi berdasarkan level agar terlihat hanya di level tertentu saja dan di bawah level tersebut.

- Menu Kelompok dimodifikasi untuk tujuan sistem CSCL yaitu penambahan siapa yang menjadi Ketua Kelompok.

- Menu Tugas dimodifikasi sehingga saat pengumpulan tugas Kelompok dapat dilakukan oleh setiap anggota secara berulang kali (diskusi Kelompok). Hanya Ketua Kelompok yang dapat mengesahkan tugas untuk dikumpulkan ke Dosennya.

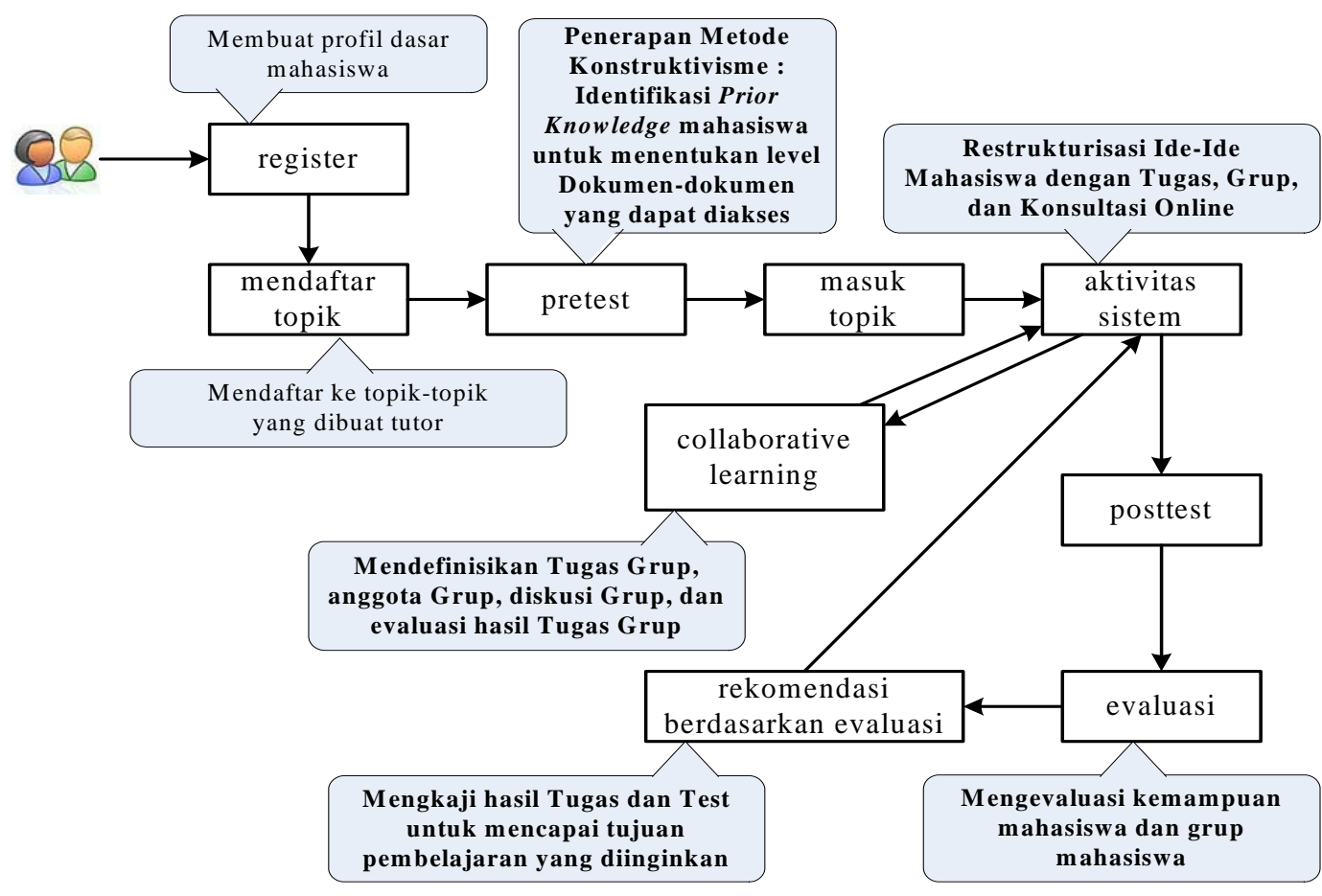

Gambar 3 Pemodelan sistem yang diusulkan

Sistem yang akan diusulkan ini dapat dimodelkan seperti pada Gambar 3. Dari Gambar 3 , proses yang terjadi pada sistem dapat dijelaskan dalam beberapa tahap, yaitu:

1. Dosen dan Mahasiswa melakukan registrasi untuk mendapatkan account. Konfirmasi account dapat dilakukan via email maupun secara langsung.

2. Dosen membuat topik baru, mendeskripsikan topik yang dibuat, dan mengisi pertanyaanpertanyaan dalam form pretest. Mahasiswa mendaftar ke topik-topik yang dibuat oleh Dosen. 
3. Mahasiswa mengisi pretest untuk mengidentifikasi pengetahuan awal mahasiswa tentang topik yang akan diikuti. Hasil pretest ini akan menentukan level mahasiswa terhadap topik tersebut dan akan berpengaruh pada dokumen-dokumen sesuai level yang dapat diakses mahasiswa. Aktivitas sistem dapat diarahkan dalam alur pembelajaran, yaitu pembelajaran kolaboratif. Kegiatan kolaboratif berada di menu kelompok, tugas, forum, tes latihan, wiki dan chat.

4.Dosen membuat posttest pada akhir masa pembelajaran terhadap masing-masing Mahasiswa.

5. Dosen mengevaluasi peningkatan pengetahuan Mahasiswa dengan membandingkan hasil pretest dan posttest.

6. Dosen memberi rekomendasi berdasarkan evaluasi terhadap Mahasiswa yang hasil Posttest kurang dari standar yang diharapkan. Rekomendasi ini dapat berupa pemberian tugas maupun tes ulang terhadap Mahasiswa tersebut.

\subsection{Skenario Pengujian}

Skenario pengujian dilakukan dengan mahasiswa harus login. Jika login sudah disetujui maka mahasiswa dapat mendaftar ke materi topik perkuliahan yang ingin diikuti. Use case untuk skenario pengujian sistem dapat dilihat pada Gambar 4.

\subsubsection{Pretest}

Saat memasuki topik perkuliahan mahasiswa diwajibkan mengisi Pretest yang soalsoalnya telah ditentukan oleh dosen pengampu perkuliahan. Pretest hanya dijawab sekali oleh mahasiswa, dan tidak dapat dilihat kembali atau diisi kembali jika pretest sudah pernah dilakukan. Total ada 4 level yang diatur dalam sistem ini.

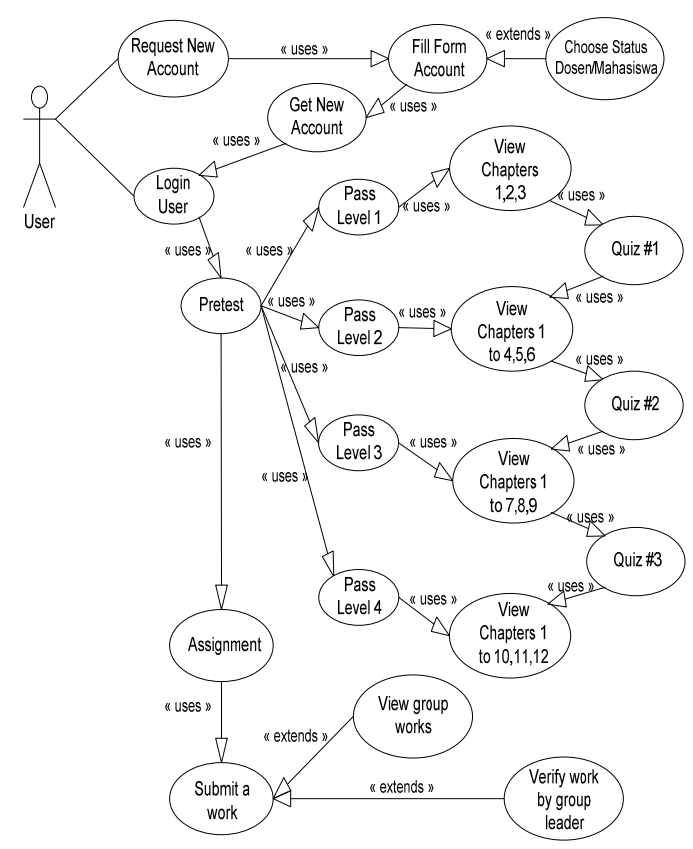

Gambar 4 Use case skenario pengujian SCK

\subsubsection{Quiz}

Dosen menentukan kapan dibuat quiz untuk naik ke level selanjutnya. Quiz dapat dibuat pada menu Tes Latihan. Quiz telah dimodifikasi untuk level tertentu sehingga dapat digunakan dosen untuk memberikan tes kenaikan level pada mahasiswa. Perbedaan menu Tes Latihan yang asli dengan yang modifikasi terletak pada penambahan kolom level pada modifikasinya. 
ISSN 2089-8673

Jurnal Nasional Pendidikan Teknik Informatika (JANAPATI)

Volume 1, Nomor 1, Maret 2012

\subsubsection{Posttest}

Di akhir masa pembelajaran dosen dapat memberikan posttest untuk menilai tingkat pemahaman mahasiswa terhadap topik yang diberikan. Mahasiswa diberikan pertanyaan pilihan unik yang sama dengan pertanyaan pada Pretest untuk melihat tingkat keberhasilan pembelajaran dengan sistem ini. Tampilan menu Tes Latihan yang berisi pengaturan level Quiz dan Posttest dapat dilihat pada Gambar 5 berikut ini.

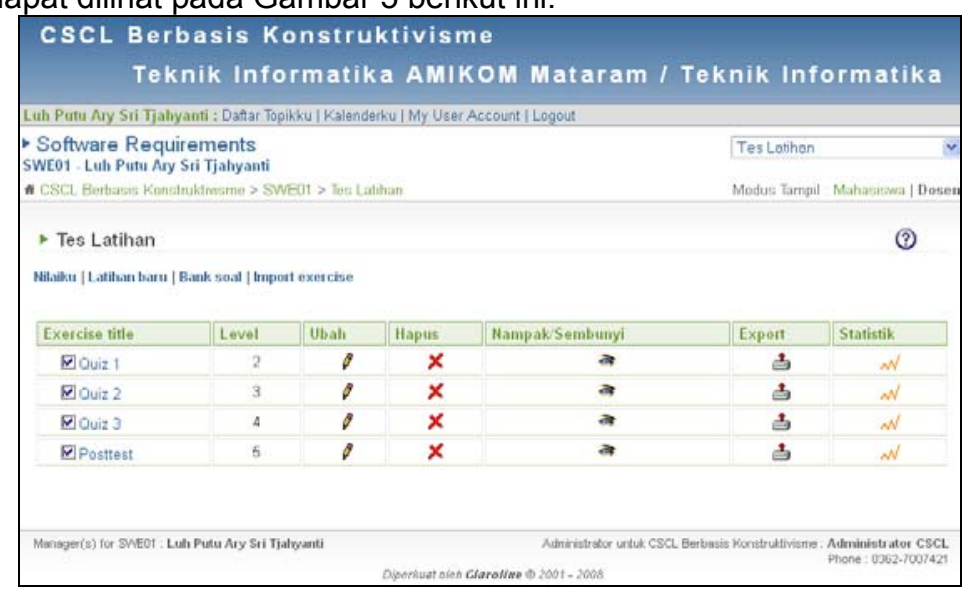

Gambar 5 Quiz kenaikan level pada menu Tes Latihan

\subsection{Uji Reliabilitas Instrumen Kuisioner}

Instrumen penelitian yang digunakan untuk mengukur tingkat kepuasan pemakai terhadap sistem yang telah dibuat yaitu Kuisioner Pemakaian (Usability Questionnaire). Instrumen ini dapat diuji tingkat kepercayaannya (reliabilitas) dengan mengukur koefisien reliabilitas instrumen (Cronbach Alpha) [8]. Rumus koefisien reliabilitas instrumen sebagai berikut.

$$
r=\left[\frac{k}{(k-1)}\right]\left[1-\frac{\sum \sigma_{b}^{2}}{\sigma_{i}^{2}}\right]
$$

dengan

$$
\begin{array}{ll}
r & =\text { koefisien Cronbach Alpha } \\
k & =\text { banyaknya butir pertanyaan } \\
\sum \sigma_{b}^{2} & =\text { total varians butir } \\
\sigma_{i}^{2} & =\text { total varians peserta } \\
b_{i} & =\text { banyaknya butir pilihan }(i=1, \ldots, k) \\
p_{i} & =\text { peserta ke- } i \text { yang terlibat }
\end{array}
$$

Nilai-nilai untuk pengujian reliabilitas berasal dari skor-skor item angket yang valid. Item yang tidak valid tidak dilibatkan dalam pengujian reliabilitas. Interpretasi reliabilitas menggunakan pertimbangan berikut ini.

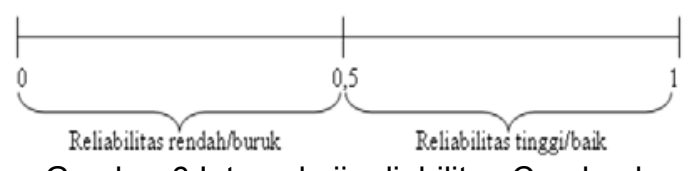

Gambar 6 Interval uji reliabilitas Cronbach

\section{Hasil dan Diskusi}

\subsection{Pengujian Sistem eLearning SCK}


ISSN 2089-8673

Jurnal Nasional Pendidikan Teknik Informatika (JANAPATI)

Volume 1, Nomor 1, Maret 2012

Pengujian penerapan SCK telah dilakukan pada topik perkuliahan Software Requirements, salah satu topik perkuliahan Rekayasa Perangkat Lunak di Jurusan Teknik Informatika AMIKOM Mataram. Berikut screenshot SCK yang dihasilkan.

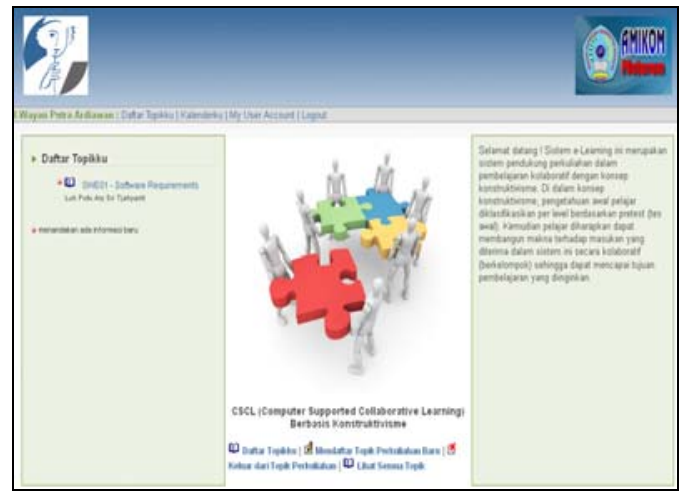

(a)

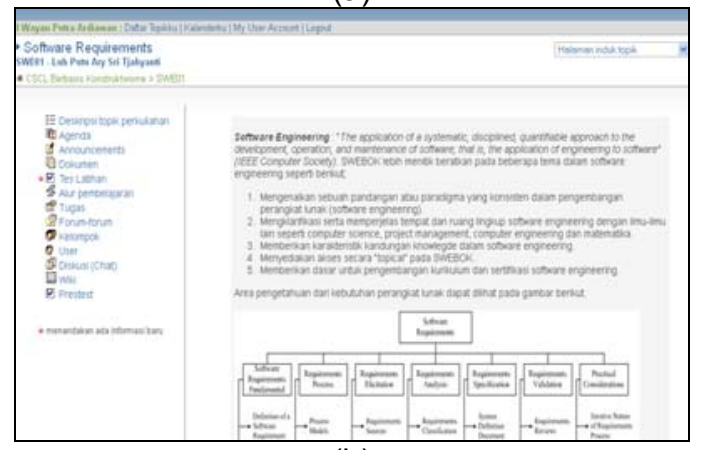

(b)

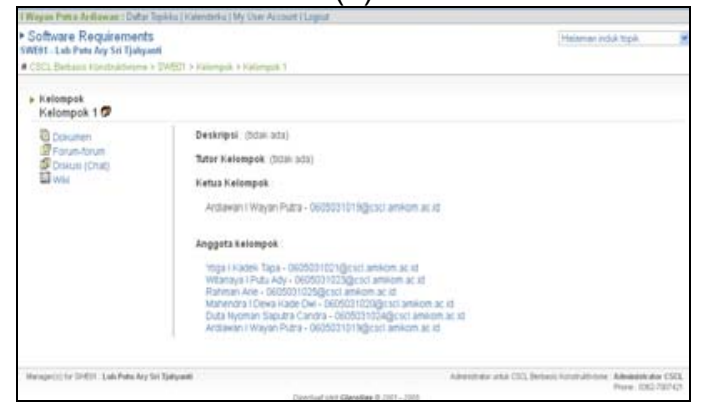

(c)

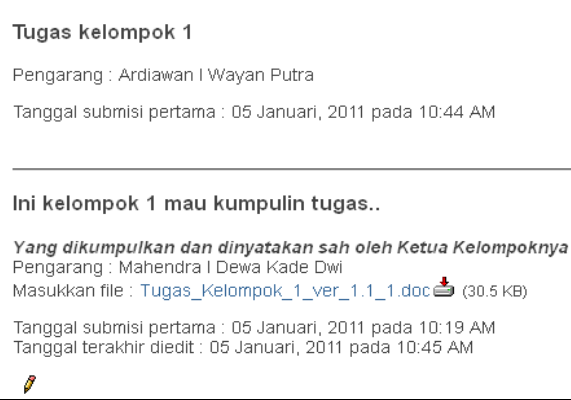

(d) 
ISSN 2089-8673

Jurnal Nasional Pendidikan Teknik Informatika (JANAPATI)

Volume 1, Nomor 1, Maret 2012

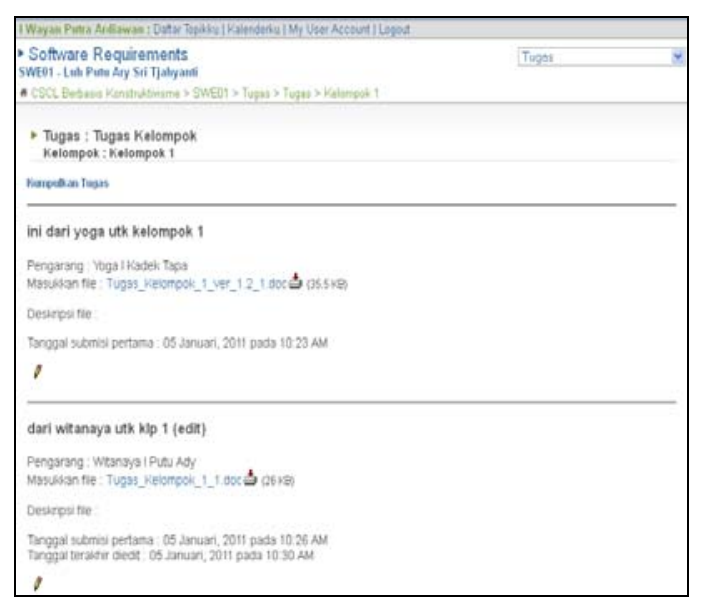

(e)

Gambar 7 (a) Tampilan login Mahasiswa; (b) Tampilan menu utama mahasiswa untuk topik Software Requirements; (c) Tampilan menu Kelompok; (d) Tampilan pengumpulan tugas dari Kelompok 1 (Anggota Kelompok); (e) Tampilan pengumpulan tugas Kelompok 1 (Ketua Kelompok)

Dari Gambar 7d dan 7e tampak ketua kelompok diberikan hak untuk mengedit dan mendownload semua berkas pengumpulan tugas dari anggota kelompoknya. Sedangkan Anggota kelompok hanya berhak mengedit dan mendownload berkas terakhir saja. Dokumen yang dikumpulkan oleh anggota kelompok dimodifikasi dengan mengatur versinya. Ketua kelompok kemudian dapat mengesahkan berkas yang dianggap final untuk dikumpulkan ke dosen seperti Gambar 8, sehingga yang dilihat oleh dosen hanyalah berkas yang disahkan saja.

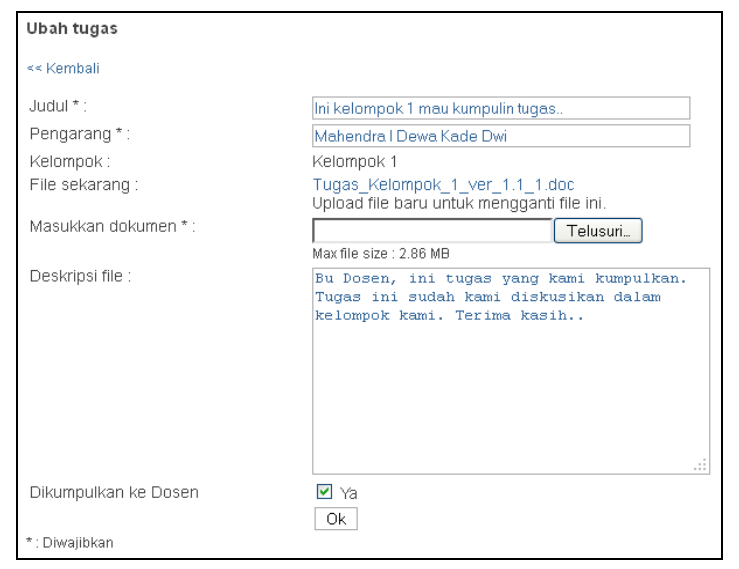

Gambar 8 Tampilan edit/ubah tugas dari ketua kelompok

Uji coba dilakukan di Jurusan Teknik Informatika AMIKOM Mataram pada topik Software Requirements pada mata kuliah Rekayasa Perangkat Lunak. Hasil uji coba yang dilakukan pada 30 orang mahasiswa dapat dilihat pada tabel berikut.

Tabel 1 Hasil pengujian tes latihan (pretest, quiz, dan posttest) 
ISSN 2089-8673

Jurnal Nasional Pendidikan Teknik Informatika (JANAPATI)

Volume 1, Nomor 1, Maret 2012

\begin{tabular}{|c|c|c|c|c|c|}
\hline Mhs & $\begin{array}{c}\text { Pretest } \\
\text { (20 soal) }\end{array}$ & $\begin{array}{c}\text { Quiz } 1 \\
\text { (10 soal) }\end{array}$ & $\begin{array}{c}\text { Quiz } 2 \\
\text { (10 soal) }\end{array}$ & $\begin{array}{c}\text { Quiz } 3 \\
(10 \text { so al) }\end{array}$ & $\begin{array}{l}\text { Posttest } \\
\text { (20 so al) }\end{array}$ \\
\hline$\overline{c 1}$ & $\overline{6}$ & $\bar{~} 6$ & 8 & 8 & 15 \\
\hline 2 & 10 & - & 8 & 8 & 18 \\
\hline 3 & 8 & 8 & 7 & 5 & 18 \\
\hline 4 & 8 & 9 & 7 & 8 & 16 \\
\hline 5 & 7 & 8 & 7 & 4 & 17 \\
\hline 6 & 14 & - & - & 5 & 18 \\
\hline 7 & 9 & - & 7 & 5 & 16 \\
\hline 8 & 12 & - & 8 & 6 & 17 \\
\hline 9 & 17 & - & - & - & 18 \\
\hline 10 & 10 & - & 7 & 8 & 15 \\
\hline 11 & 8 & 10 & 6 & 8 & 16 \\
\hline 12 & 11 & - & 7 & 8 & 19 \\
\hline 13 & 9 & - & 5 & 6 & 17 \\
\hline 14 & 17 & - & - & - & 19 \\
\hline 15 & 5 & 10 & 8 & 9 & 14 \\
\hline 16 & 9 & - & 7 & 8 & 18 \\
\hline 17 & 4 & 10 & 7 & 7 & 12 \\
\hline 18 & 9 & - & 7 & 9 & 17 \\
\hline 19 & 3 & 7 & 5 & 9 & 13 \\
\hline 20 & 5 & 6 & 8 & 6 & 16 \\
\hline 21 & 11 & - & 6 & 7 & 15 \\
\hline 22 & 13 & - & - & 8 & 15 \\
\hline 23 & 18 & - & - & - & 20 \\
\hline 24 & 8 & 8 & 7 & 7 & 16 \\
\hline 25 & 7 & 9 & 7 & 6 & 14 \\
\hline 26 & 7 & 7 & 7 & 8 & 14 \\
\hline 27 & 8 & 10 & 6 & 7 & 15 \\
\hline 28 & 12 & - & 8 & 6 & 17 \\
\hline 29 & 10 & - & 7 & 8 & 16 \\
\hline 30 & 6 & 10 & 7 & 8 & 16 \\
\hline Rerata & 4.68 & 8.43 & 6.92 & 7.11 & 8.12 \\
\hline
\end{tabular}

Dari tabel 1 didapatkan nilai rata-rata Pretest sebesar 4,68 dan nilai rata-rata Posttest sebesar 8,12 . Sehingga terjadi peningkatan sebesar 3,44 selama pembelajaran berlangsung. Hal ini berarti sistem CSCL berbasis Konstruktivisme ini memberikan kontribusi yang besar dalam meningkatkan hasil pembelajaran.

\subsection{Evaluasi Sistem dengan Kuesioner Pemakaian (Usability Questionnaire)}

Evaluasi SCK dapat dilakukan dengan kuesioner pemakaian yang diadopsi dari metode evaluasi pemakaian oleh Zakarias [9]. Kuesioner ini diberikan setelah pelatihan SCK terhadap 10 dosen dan 30 mahasiswa yang totalnya 40 orang. Hal ini berarti data yang dikelola terdiri dari 40 responden.

Dari hasil penelitian dapat disimpulkan rata-rata penilaian sistem sebagai berikut. Ratarata yang menyatakan Tidak Setuju (TS) sebesar 2,81\%, Netral (N) sebesar 12,77\%, Setuju (S) sebesar 66,67 \%, dan Sangat Setuju (SS) sebesar 17,75\%. Sehingga sistem ini dianggap disetujui oleh sebagian besar penggunanya dengan rata-rata yang setuju sebesar $84,42 \%$ (S + SS).

\subsection{Uji Koefisien Reliabilitas Cronbach}

Dari hasil pengujian didapat varians butir pertanyaan $\sigma_{1}{ }^{2}=0,75, \sigma_{2}{ }^{2}=2,89, \sigma_{3}{ }^{2}=6,22$, $\sigma_{4}^{2}=5,84$ sehingga totalnya 15,71 . Untuk total varians peserta didapat $\sigma_{i}^{2}=27,5$. Dari nilai total varians di atas dapat dicari nilai koefisien reliabilitas Cronbach seperti persamaan (1) sebagai berikut.

$$
r=\left[\frac{4}{(4-1)}\right]\left[1-\frac{15,71}{27,5}\right]=0,57
$$




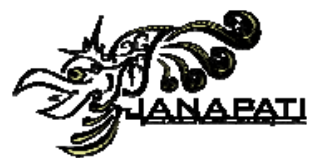

ISSN 2089-8673

Jurnal Nasional Pendidikan Teknik Informatika (JANAPATI)

Volume 1, Nomor 1, Maret 2012

Berdasarkan interval uji reliabilitas pada Gambar 6 dapat disimpulkan bahwa tingkat reliabilitas hasil kuisioner pemakaian di atas reliabilitas rendah yaitu $>0,50$. Sehingga dapat dikatakan tingkat reliabilitasnya baik.

\section{Kesimpulan}

Berikut ini beberapa kesimpulan yang dapat diambil dari penelitian ini :

1.SCK dimodifikasi dari open source e-learning Claroline dengan penambahan Pretest, pelevelan dokumen, perubahan aturan kelompok, dan perubahan aturan pengumpulan tugas kelompok.

2. Hasil pengujian pada 30 mahasiswa didapatkan nilai rata-rata Pretest 4,68 dan Posttest 8,12 . Hal ini berarti SCK memberikan kontribusi yang besar dalam meningkatkan hasil pembelajaran.

3. Hasil evaluasi sistem dengan Kuesioner Pemakaian menyatakan sebagian besar pengguna SCK setuju adanya sistem ini dengan rata-rata $84,42 \%$. Hal ini berarti SCK telah memenuhi kriteria-kriteria sistem yang diinginkan oleh penggunanya.

4. Hasil uji reliabilitas Kuesioner Pemakaian didapatkan koefisien reliabilitas (Cronbach) sebesar 0,57 yang artinya tingkat kepercayaan yang baik terhadap instrumen kuesioner yang digunakan.

\section{Saran}

Sistem CSCL berbasis Konstruktivisme ini dapat dikembangkan dari segi isi agar bisa membaca dokumen berbentuk multimedia. Sistem CSCL berbasis Konstruktivisme bila dikembangkan lebih lanjut dapat digunakan sebagai alternatif pembelajaran jarak jauh / Blanded E-learning, dan dapat juga dikembangkan sebagai alternatif materi yang diberikan di sekolah Home Schoolling.

\section{Daftar Pustaka}

[1] Toshio Okamoto. (2004). Collaborative Technology and New e-Pedagogy. Proceedings of the IEEE International Conference on Advanced Learning Technologies (ICALT'O4).

[2] Xinhua He dan Wenfa Hu (2008), "An Innovative Web-Based Collaborative Learning Model and Application Structure", 2008 International Conference on Comp. Sci. and Software Eng., IEEE Computer Society, pp. 56-59.

[3] Wu Junqi, et. al.. (2009). Design of Collaborative Learning in Cyber-schools. First International Workshop on Database Technology and Applications, 978-0-7695-3604-0/09, pp.703-706.

[4] Xinyu D., Li Min. (2008). Design of Computer Supported Collaborative Learning System Based on Learning Contract. International Conference on Computer and Electrical Engineering, IEEE Computer Society 978-0-7695-3504-3/08, pp.181-184.

[5] Zhao R. et. al.. (2009). A Framework for Collaborative Learning System Based on Knowledge Management. 2009 First International Workshop on Education Technology and Computer Science, IEEE Computer Society, pp. 733-736.

[6] Lan Yu-Feng, et. al. (2009). Designing an Efficient Collaborative Learning Model to Construct a Consensus Based on Binary Tree Structure. Fifth International Joint Conference on INC, IMS and IDC, 978-0-7695-3769-6/09, pp.182-187.

[7] Melissa, C. (2009). Using Wiki technology to support student engagement: Lessons from the trenches. Computers \& Education.

[8] Juliandi Azuar. (2010). Uji Reliabilitas Instumen Penelitian dengan Cronbach Alpha (Manual). http://www.azuarjuliandi.com, diakses terakhir tanggal 23 Juni 2011.

[9] P. Zacharias and A. Poulymenakou. (2009). Developing a usability evaluation method for elearning applications: Beyond functional usability. In International Journal of HumanComputer Interaction, 25(1):75-98. 